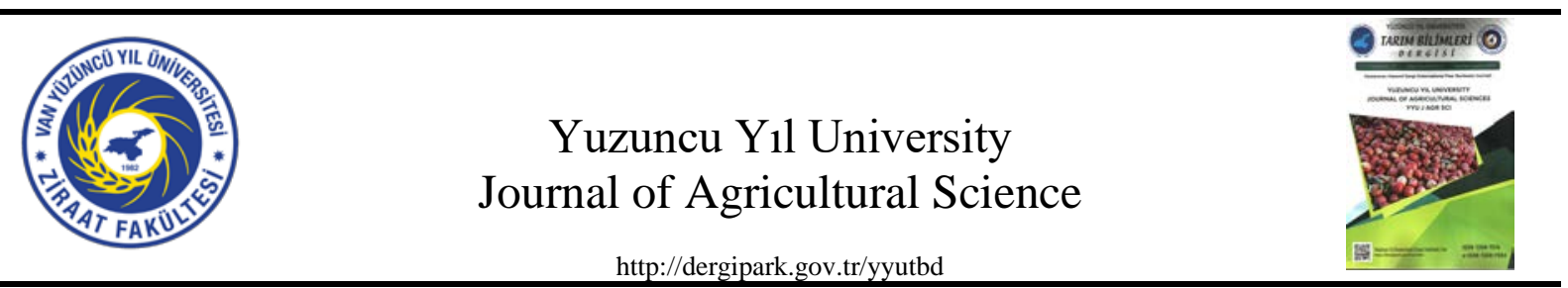

Research Article (Araştırma makalesi)

Determination of Genetic Relations among Tomato Accessions in Sulaymaniyah Region through ISSRs Markers Genetic Relations in Tomato Accessions

\author{
Abdulrahman Smail IBRAHIM ${ }^{1}$, Ceknas ERDINC*1,2 \\ ${ }^{1}$ Van Yuzuncu Yil University, Natural \& Applied Sciences Institute, Agricultural Biotechnology, Van, Turkey \\ ${ }^{2}$ Van Yuzuncu Yil University, Faculty of Agriculture, Agricultural Biotechnology Department, Van, Turkey \\ ${ }^{1}$ https://orcid.org/0000-0002-0714-6585 ${ }^{2}$ https://orcid.org/0000-0003-1208-032X \\ *Corresponding author e-mail: ceknaserdinc@yyu.edu.tr
}

\section{Article Info \\ Received: 19.06.2020 \\ Accepted: 20.10.2020 \\ Online Published 31.12.2020 \\ DOI: $10.29133 /$ yyutbd.755083}

Keywords

Genetic variation,

ISSR,

Solanum lycopersicum L,

Sulaymaniyah.

\begin{abstract}
The goal of this study was to examine the genetic difference among thirty two tomato accessions (Solanum lycopersicum L.) grown in Sulaymaniyah using ISSR molecular markers technique. The results of ISSR markers revealed 65 amplified fragments, 50 of them were polymorphic from using 15 primers. Fifteen ISSR markers used to detect DNA polymorphism gave polymorphism percentage for each primer range between $50-100 \%$ with an average polymorphism percentage reaching $75.61 \%$. ISSR6 and Sola 11 gave the highest polymorphism percentage was $100 \%$, while $3 \mathrm{~F}$, Sola 5 and Sola 12 did not give any amplification. The mean of PIC (Polymorphic Information Content) value was 0.50 for ISSR markers. The similarity matrix was obtained by using Jaccard's coefficients, based on polymorphic bands and dendrogram constituted through UPGMA cluster analysis. The dendrogram revealed 4 main groups. Genetic similarity (GS) ranged from 0.261 to 0.941 within studied accessions. The highest similarity was 0.941 for the genotype pairs G7 and G16. However, the lowest similarity index was 0.261 among G15-G24 and G15-G26. Tomato accessions were determined by two populations according to STRUCTURE analysis. The ISSR marker system ensured useful information in describing genetic diversity among tomato accessions collected from different geographical around Sulaymaniyah province.
\end{abstract}

\title{
Süleymaniye Bölgesindeki Domates Genotipleri Arasındaki Genetik İlişkilerin ISSR Belirteçleri ile Belirlenmesi
}

\section{Makale Bilgileri}

Geliş: 19.06 .2020

Kabul: 20.10.2020

Online Yayınlanma 31.12.2020

DOI: $10.29133 /$ yyutbd.755083

\section{Anahtar kelimeler}

Genetik çeşitlilik,

ISSR,

Solanum lycopersicum L, Süleymaniye.

\begin{abstract}
Öz: Çalışmada Süleymaniye bölgesinde yetiştirilen 32 domates (Solanum lycopersicon L.) genotipi arasındaki genetik çeşitliliğin ISSR belirteç tekniği kullanarak belirlemek amaçlanmıştır. ISSR primerlerinin sonuçları, 15 primerden 65 amplifikasyon oluştuğunu ve bu amplifikasyonların 50'sinin polimorfik olduğunu ortaya çıkarmıştır. Polimorfizmi belirlemek için kullanılan 15 ISSR primeri \% 50-100 arasında polimorfizm oranına sahip olmuş ve ortalama polimorfizm oranının \% 75.61 olduğu belirlenmiştir. ISSR primerlerinin PIC değeri ortalaması 0.50 olarak tespit edilmiştir. Benzerlik matriksi polimorfik bant varlığın bağlı olarak Jaccard benzerlik katsayısı ile hesaplanmış ve UPGMA yöntemine göre kümeleme analizi ile dendogram elde edilmiştir. Dendogramda 4 temel grup oluştuğu belirlenmiştir. Genotipler arasındaki genetik benzerlik (GS) katsayıları 0.261 ile 0.941 arasında değişiklik göstermiştir. En yüksek benzerlik 0.941 benzerlik katsayısı ile G7 ve G16 genotipleri arasında olurken, en düşük benzerlik 0.261 ile G15-G24 ve G15-G26 arasında bulunmuştur. STRUCTURE analizine göre ise genotiplerin iki populasyona ayrıldıkları saptanmıştır. ISSR yönteminin Süleymaniye'nin farklı bölgelerinden toplanmış domates genotipleri arasındaki genetik çeşitliliği tanımlamada etkili olduğu belirlenmiştir.
\end{abstract}




\section{Introduction}

Tomato cultivation has always been a very important part of agriculture in most countries of the world. It is an important source of vitamin. The tomato genetic resources are vital for conventional and molecular breeding, and determination of their genetic differences has valuable potential in the tomato industry. Tomato also has been used as model plant species in studies such as the physiology and biochemistry of seed development, germination and dormancy (Suhartanto, 2002). There have been carried out many studies to evaluate the genetic variety of tomato by morphological, biochemical and molecular markers (Abak et al., 1996; Powell et al., 1996; Tam et al., 2005; Terzopoulos and Bebeli, 2008; Bayram et al., 2011; Vishwanath et al., 2011).

The application of molecular markers in plant breeding programs facilitates the improvement of many crop species (Williams, et al., 1990). Nowadays, several molecular markers are developed, of which Inter Simple Sequence Repeats (ISSRs) are one of the widely used types. ISSRs molecular markers that enhance regions between microsatellite loci does not need any information about the sequences to be amplified and shows high polymorphism in the material, being exceptionally helpful in investigations of genetic variation, phylogeny, and genomics (Reddy et al., 2002). This marker (ISSR) technique can handle the above limitations (Pharmawati et al., 2004; Reddy et al., 2002). The ISSR markers have been studied by several researchers for molecular characterization of many plant species such as tomato (Kamel et al., 2010), rice bean (Muthusamy et al., 2008), common bean (Erdinc et al., 2017; Ekincialp and Sensoy, 2018), melon (Erdinç et al., 2013) and coffee (Masumbuko and Bryngelsson, 2006).

The evaluation of genetic diversity within and between populations of tomato landraces is estimated by using morphological, biochemical and molecular characterization (Antonio et al., 2004). In recent years, an important decrease of genetic variability was observed in especially several fruit quality traits of the cultivated tomato (Foolad, 2007). Tomato is one of the economic important crops in Iraq and there are local tomato accessions. It is important that bringing out genetic relations among these accessions for next breeding studies. Therefore, this study was aimed to assess the genetic variety and relationship of 32 tomato accessions locally collected from different regions in from Sulaymaniyah governorate as revealed by ISSR markers.

\section{Material and Methods}

\subsection{Material}

Thirty two tomato landraces (Solanum lycopersicum L.) accessions collected from different regions province of Sulaymaniyah-Iraq was used in this study (Table 1).

Table 1. Origin of tomato accessions used in this study

\begin{tabular}{llll}
\hline Accession \# & Origin & Accession \# & Origin \\
\hline G1 & Sindolan & G17 & Mergapan \\
G2 & Isawi (small size) & G18 & Suse \\
G3 & Isawi (big size) & G19 & Badawa \\
G4 & Beshir & G20 & Beklo \\
G5 & Kfradol & G21 & Khdran \\
G6 & Hero & G22 & Halsho \\
G7 & Said Ahmadan & G23 & Mamanda \\
G8 & Yaran Bagi & G24 & Penjuin \\
G9 & Chwas & G25 & Dawdya \\
G10 & Sangasar & G26 & Bokriskan \\
G11 & Sangaw & G27 & Benasa \\
G12 & Shekhawdalan & G28 & Salara \\
G13 & Ashkana & G29 & Kalar \\
G14 & Shene & G30 & Begalas \\
G15 & Bawze & G31 & Gira \\
G16 & Saruchawa & G32 & Swru \\
\hline
\end{tabular}




\subsection{Methods}

For genomic DNA isolation, seedlings were grown in a growth chamber at a temperature of $24^{\circ} \mathrm{C}$ with a $16 / 8 \mathrm{~h}$ day/night photoperiod. Each replicate included 10 seeds per accession. Genomic DNA was extracted in bulk from young fresh leaves employing the CTAB procedure with minor modifications (Doyle and Doyle, 1987). DNA was quantified by Nano Drop, ND 100 spectrophotometer (Nano Drop Technologies, Inc.). DNA were diluted in water to a final concentration of $50 \mathrm{ng}$ and stored at $-20^{\circ} \mathrm{C}$.

Fifteen primers of ISSR were utilized in our study is shown in Table 2. The PCR amplification was performed using a $25 \mu \mathrm{l}$ mixture contained the following components: $8.7 \mu \mathrm{l}$ of sterile $\mathrm{ddH}_{2} \mathrm{O}, 1 \mathrm{X}$ Taq buffer, $2.5 \mathrm{mM}$ of $\mathrm{MgCl}_{2}(25 \mathrm{mM}), 0.6 \mathrm{mM}$ of primer , $0.1 \mathrm{mM}$ of dNTPs, 1 unit of Taq polymerase and $50 \mathrm{ng}$ of template DNA. PCR amplification included a denaturing stage at $94{ }^{\circ} \mathrm{C}$ for 3 minutes, followed by 35 cycles denaturing step at $94{ }^{\circ} \mathrm{C}$ for $20 \mathrm{~s}$, an annealing step at a temperature according the melting temperature of each primer (Table 2) for $40 \mathrm{~s}$ and an extension step at $72{ }^{\circ} \mathrm{C}$ for 1 minute. After the last cycle the samples were kept for $10 \mathrm{~min}$ at $72{ }^{\circ} \mathrm{C}$ (Terzopoulos and Bebeli, 2008).

PCR products were electrophoresed on 1.5\% agarose gel in 1X TAE buffer at $120 \mathrm{~V}$ for $2.5 \mathrm{~h}$. Amplified products were photographed using an Imager Gel Doc XR system (Vilber Lourmat, QUANTUM ST4).

\subsection{Data analysis}

Reproducible and legible bands were scored as 1 (existence) and 0 (absence) according to binary system. Genetic distance among tomato accessions was calculated by using Jaccard similarity coefficients and UPGMA method was used with the similarity coefficient to construct the dendrograms showing genetic diversity with software PAST3. Also, basic coordinate analysis (PCoA) was performed with the same program. The PIC (polymorphic information content) was calculated using the following standard formula (Powell et al., 1996; Smith et al., 1997). According to the "fi" explain the markers frequency in data set.

$$
\mathrm{PIC}=1-\sum \mathrm{fi}^{2}
$$

Population structure was analyzed with the Bayesian model-based clustering algorithm using the software STRUCTURE ver. 2.3.2 (Pritchard et al. 2000).

\section{Results and Discussion}

In this study, fifteen of the eighteen ISSR primers produced legible band. Total 65 DNA fragments were detected from ISSR primers (Table 2) and 50 of them were polymorphic. While the mean of polymorphic band number was 3.33 , the highest polymorphic band was obtained from primer 816 (7.00). Primer 10F gave the lowest polymorphic band number (1.00). Polymorphism level was calculated for the fifteen ISSR primers and polymorphism was range between $50-100 \%$ and the average polymorphism was $75.61 \%$. Primer $10 \mathrm{~F}$ gave the lowest polymorphism with $50 \%$ while the highest polymorphism was $100 \%$ in ISSR6 and Sola 11 . The mean of PIC was 0.50 and PIC value of ISSR primers was ranged 0.06-0.95. While PHV6 had the lowest PIC (0.06), primer 10F showed the highest PIC value with 0.95 . 
Table 2. Number of band, polymorphism and PIC values of ISSR primers used this study

\begin{tabular}{|c|c|c|c|c|c|c|}
\hline $\begin{array}{c}\text { ISSR } \\
\text { primers }\end{array}$ & Sequence (5'-3') & $\begin{array}{l}\text { AnnealingTemp. } \\
\qquad\left({ }^{\circ} \mathrm{C}\right)\end{array}$ & $\begin{array}{l}\text { Total } \\
\text { number of } \\
\text { DNA } \\
\text { fragments }\end{array}$ & $\begin{array}{c}\text { Number of } \\
\text { polymorphic } \\
\text { DNA } \\
\text { fragments }\end{array}$ & $\begin{array}{c}\text { Polymorphism } \\
\text { (\%) }\end{array}$ & $\begin{array}{c}\text { PIC } \\
\text { value }\end{array}$ \\
\hline $12 \mathrm{~F}$ & $(\mathrm{AG})_{8} \mathrm{YG}$ & 55.0 & 6.00 & 4.00 & 66.67 & 0.64 \\
\hline $13 \mathrm{~F}$ & $(\mathrm{AC})_{8} \mathrm{YT}$ & 51.0 & 6.00 & 5.00 & 83.33 & 0.21 \\
\hline 16 & $(\mathrm{AC})_{8}$ & 57.0 & 6.00 & 5.00 & 83.33 & 0.20 \\
\hline 812 & $(\mathrm{GA})_{8} \mathrm{~A}$ & 51.0 & 3.00 & 2.00 & 66.67 & 0.86 \\
\hline 816 & $(\mathrm{AC})_{8}$ & 52.0 & 8.00 & 7.00 & 87.50 & 0.61 \\
\hline 889 & AGTCGTAGT(AC) 8 & 57.0 & 6.00 & 4.00 & 66.67 & 0.64 \\
\hline B2 & $(\mathrm{AG})_{8} \mathrm{~T}$ & 55.0 & 3.00 & 2.00 & 66.67 & 0.89 \\
\hline ISSR6 & $\operatorname{VDV}(\mathrm{GT})_{8}$ & 55.0 & 4.00 & 4.00 & 100.00 & 0.34 \\
\hline PHV6 & $\mathrm{CCA}(\mathrm{CT})_{8}$ & 57.0 & 3.00 & 2.00 & 66.67 & 0.06 \\
\hline Sola 9 & $(\mathrm{AC})_{8} \mathrm{G}$ & 52.0 & 4.00 & 3.00 & 75.00 & 0.33 \\
\hline Sola11 & GAG-(CAA) $)_{5}$ & 51.0 & 2.00 & 2.00 & 100.00 & 0.25 \\
\hline $10 \mathrm{~F}$ & $(\mathrm{GT})_{8} \mathrm{YC}$ & 55.0 & 2.00 & 1.00 & 50.00 & 0.95 \\
\hline 13 & $(\mathrm{CCA})_{5}$ & 55.0 & 5.00 & 4.00 & 80.00 & 0.20 \\
\hline 825 & $(\mathrm{AC})_{8} \mathrm{~T}$ & 52.0 & 3.00 & 2.00 & 66.67 & 0.82 \\
\hline Sola 4 & VHV-(GT) $)_{7} \mathrm{G}$ & 55.0 & 4.00 & 3.00 & 75.00 & 0.48 \\
\hline Total & & & 65.00 & 50.00 & & \\
\hline Mean & & & 4.33 & 3.33 & 75.61 & 0.50 \\
\hline
\end{tabular}

The high degree of polymorphism and the number of polymorphic bands obtained per assay showed that ISSR is one of the most informative marker systems for tomato genotyping as well as other crop species (Erdinç et al., 2013; Erdinc et al, 2017; Ekincialp et al., 2019; Topaklı and Hepaksoy, 2019). The highest percentage of polymorphism was obtained from primer ISSR6 and Sola 11 that is $100 \%$, while the lowest percentage of polymorphism was from primer 10F. All of the ISSR primers gave a good percentage of polymorphism. ISSR markers used in this study were mostly polymorphic with a total 50 numbers polymorphic, while the total polymorphic was 81 in another experiment (Todorovska et al., 2014). (Terzopoulos and Bebeli, 2008) obtained $57.8 \%$ polymorphism and 59 polymorphic bands from 12 ISSR primers in Greek tomato landraces. (Tikunov et al., 2003) found a polymorphism level between 60 to 89\%, while (Suliman-Pollatschek et al., 2002) reproduced the polymorphism as 65\%. Alternatively, (Meng et al., 2010) found more polymorphic bands ranged from 4 to 18 with an average of 7.91. There are some studies in tomato which gave lower average number of bands and polymorphism level. (Figueiredo et al., 2016) found in 8 ISSR primers 2.62 numbers of polymorphic band and 27.62\% polymorphism level. (Aguilera et al., 2011) obtained 34.02\% polymorphism level, while (Shahlaei et al., 2014) found 2.5 numbers of polymorphic band and $8.84 \%$ polymorphism level. Most of ISSR primers gave high degree polymorphism (over 70\%) and were successful to amplify the accessions of tomato visibly. Some of ISSR primers used to this research gave same percentage of polymorphism in other studies. (Kochieva et al., 2002; Korir et al., 2014), while (Vargas-Ponce et al., 2011; Henareh et al., 2016) obtained $100 \%$ polymorphism level from all primers they used. Generally polymorphic information content (PIC) of ISSR primers was high and 7 primers had over $60 \%$ PIC. There are some studies which ranged from 0.06 to 0.64 and 0.09 to 0.67, respectively (Bredemeijer et al., 1998; He et al., 2003). Furan and Geboloğlu, (2017) and Erdinc et al., (2017) found PIC values of ISSR primers between $0.28-0.44$ and $0.15-0.50$, respectively.

The similarity index matrix was obtained to compare genetic variation among the 32 tomato accessions using ISSR primers (Table 3). Jaccard similarity coefficient of accessions based on fifteen ISSR markers ranged from 0.261 to 0.941 . The most different tomato accessions were G15 (0.370), G28 (0.538) and G9 (0.630), while the most similar tomato accessions were G11 (0.768), G17 (0.767) and G20 (0.766). The lowest genetic distance was observed among pair of accessions G15-G24 and G15G26 (0.261) and G15-G30 (0.269), while the highest genetic distance was noted in G7-G16 (0.941), G27-G29 (0.933) and G20-G27 (0.930). Cluster analysis was performed to determine genetic relationships among 32 tomato accessions using pair-wise genetic similarity values by UPGMA based on Jaccard coefficient. According to genetic distance matrix dendogram (Figure 1) divided into four 
main groups: First group (Branch I) and the second group (Branch II) included only one accession (respectively G15 and G28). Branch III had G1 and G9 accessions. Branch IV contained 28 accessions and this group was also divided into subgroups. (Thamir et al., 2014), found that genetic similarity ranged from 0.229 to 0.946 among 19 Iraq tomato accessions and they divide into two main groups. Similarly, SSR markers were used to determine genetic relationships among tomato accessions in Iraq and genetic similarity coefficient was between 0.324-0.917 (Al-Tamimi et al., 2015). While (GarcíaMartínez et al., 2006) had close similarity indices among their tomato accessions in another study the values of pair-wise genetic distances ranged from 0.1838 - 0.9049, indicating the attendance of extensive genetic diversity (Tabassum et al., 2013). (Sharifova et al., 2013) had also obtained dendrogram for discrimination among tomato accessions with 0.188-1.000 similarity coefficient. (Terzopoulos and Bebeli., 2008) found genetic similarity values ranged from 0.56 to 0.95 with an average of 0.797 among 41 tomato accessions. (Aguilera et al., 2011) studied 96 tomato accessions by ISSR markers and genetic distance ranged from 0 to 0.25 . In addition, they pointed out that this marker system has a high efficiency to distinguish accessions. In another different study, 12 modern tomato varieties were used to assign genetic relation. There was obtained Jaccard's coefficient between 0.12-0.88 and varieties were distinguished to 4 main clusters in UPGMA based dendrogram (Kiani and Siahchehreh, 2018).
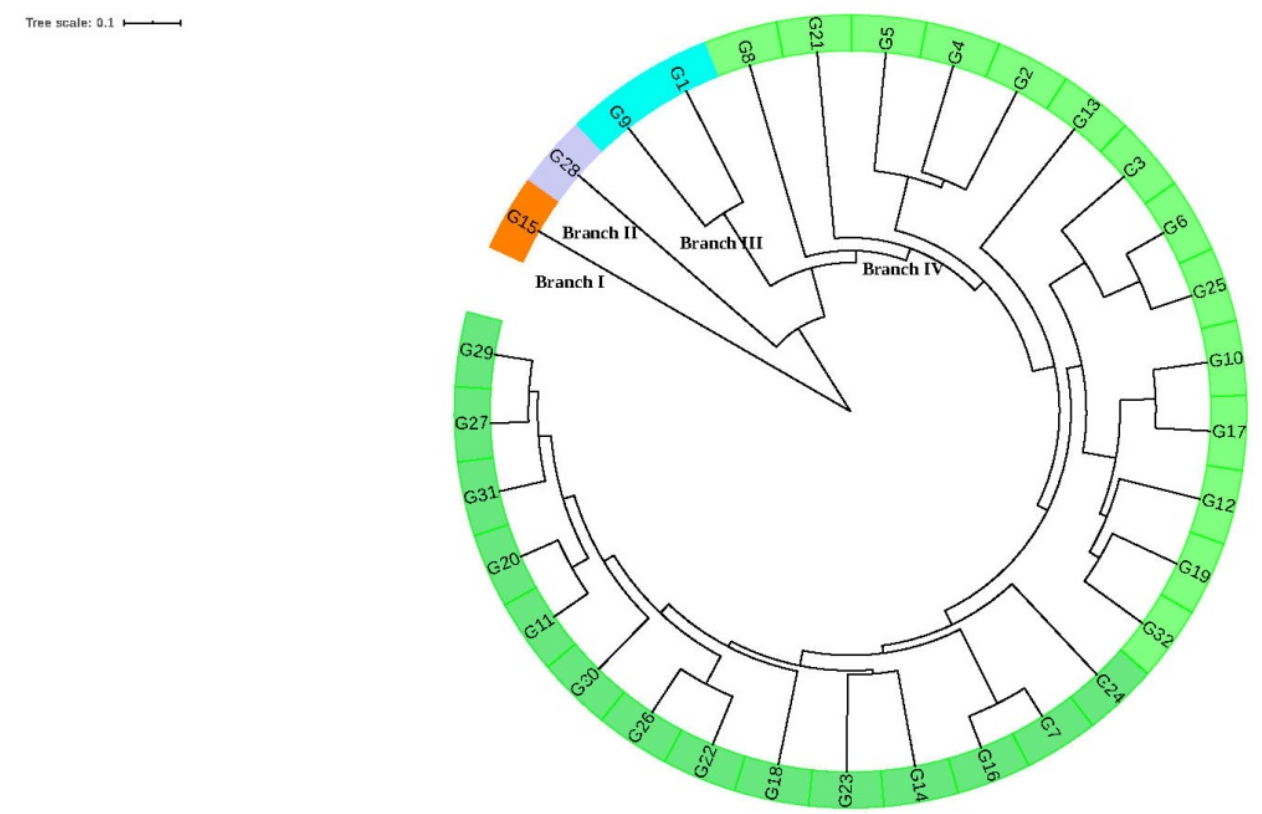

Figure 1. UPGMA-based clustering of accessions of 32 different tomatoes on the basis of Jaccard distance values.

PCoA cluster analysis discriminated 32 tomato accessions into 4 different groups (Group A, Group B, Group C and Group D) (Figure 2). Similarly, UPGMA-based analysis, G15 and G 28 accessions generated a single group in the PCoA analysis (Group A and Group B). While G1 and G9 took part in Group C the other accessions constituted Group D. When two cluster analysis methods were compared the results indicate that groups in PCoA and branches in UPGMA consist of the same accessions (Figure 1 and 2). It was observed that the results obtained from PCoA appropriate to the results with the UPGMA-based cluster method. 
Table 3. The similarity index by using Jaccard similarity coefficients

\begin{tabular}{|c|c|c|c|c|c|c|c|c|c|c|c|c|c|c|c|c|c|c|c|c|c|c|c|c|c|c|c|c|c|c|c|c|}
\hline & G1 & G2 & G3 & G4 & G5 & G6 & G7 & G8 & G9 & G10 & G11 & G12 & G13 & G14 & G15 & G16 & G17 & G18 & G19 & G20 & $\mathrm{G} 21$ & $\mathrm{G} 22$ & G23 & G24 & G25 & G26 & G27 & $\mathrm{G} 28$ & G29 & G30 & G31 & G32 \\
\hline G1 & 1.00 & & & & & & & & & & & & & & & & & & & & & & & & & & & & & & & \\
\hline G2 & 0.69 & 1.00 & & & & & & & & & & & & & & & & & & & & & & & & & & & & & & \\
\hline G3 & 0.69 & 0.72 & 1.00 & & & & & & & & & & & & & & & & & & & & & & & & & & & & & \\
\hline G4 & 0.67 & 0.81 & 0.79 & 1.00 & & & & & & & & & & & & & & & & & & & & & & & & & & & & \\
\hline G5 & 0.60 & 0.79 & 0.78 & 0.79 & 1.00 & & & & & & & & & & & & & & & & & & & & & & & & & & & \\
\hline G6 & 0.74 & 0.71 & 0.88 & 0.77 & 0.74 & 1.00 & & & & & & & & & & & & & & & & & & & & & & & & & & \\
\hline G7 & 0.58 & 0.61 & 0.78 & 0.65 & 0.72 & 0.76 & 1.00 & & & & & & & & & & & & & & & & & & & & & & & & & \\
\hline G8 & 0.59 & 0.61 & 0.74 & 0.63 & 0.60 & 0.63 & 0.73 & 1.00 & & & & & & & & & & & & & & & & & & & & & & & & \\
\hline G9 & 0.78 & 0.63 & 0.66 & 0.69 & 0.60 & 0.61 & 0.53 & 0.58 & 1.00 & & & & & & & & & & & & & & & & & & & & & & & \\
\hline G10 & 0.67 & 0.74 & 0.79 & 0.79 & 0.76 & 0.84 & 0.81 & 0.76 & 0.66 & 1.00 & & & & & & & & & & & & & & & & & & & & & & \\
\hline G11 & 0.61 & 0.73 & 0.79 & 0.68 & 0.74 & 0.81 & 0.83 & 0.63 & 0.60 & 0.81 & 1.00 & & & & & & & & & & & & & & & & & & & & & \\
\hline G12 & 0.72 & 0.68 & 0.77 & 0.71 & 0.68 & 0.68 & 0.69 & 0.71 & 0.78 & 0.79 & 0.75 & 1.00 & & & & & & & & & & & & & & & & & & & & \\
\hline G13 & 0.58 & 0.57 & 0.70 & 0.63 & 0.63 & 0.76 & 0.75 & 0.66 & 0.57 & 0.79 & 0.73 & 0.69 & 1.00 & & & & & & & & & & & & & & & & & & & \\
\hline G14 & 0.56 & 0.59 & 0.66 & 0.55 & 0.59 & 0.74 & 0.73 & 0.59 & 0.52 & 0.72 & 0.86 & 0.71 & 0.73 & 1.00 & & & & & & & & & & & & & & & & & & \\
\hline G15 & 0.56 & 0.43 & 0.38 & 0.50 & 0.33 & 0.37 & 0.30 & 0.50 & 0.67 & 0.37 & 0.28 & 0.39 & 0.35 & 0.28 & 1.00 & & & & & & & & & & & & & & & & & \\
\hline G16 & 0.60 & 0.67 & 0.82 & 0.69 & 0.78 & 0.83 & 0.94 & 0.69 & 0.56 & 0.84 & 0.83 & 0.72 & 0.72 & 0.75 & 0.29 & 1.00 & & & & & & & & & & & & & & & & \\
\hline G17 & 0.70 & 0.83 & 0.82 & 0.79 & 0.81 & 0.81 & 0.72 & 0.72 & 0.67 & 0.90 & 0.82 & 0.84 & 0.76 & 0.74 & 0.35 & 0.79 & 1.00 & & & & & & & & & & & & & & & \\
\hline G18 & 0.56 & 0.73 & 0.74 & 0.66 & 0.77 & 0.79 & 0.82 & 0.61 & 0.54 & 0.81 & 0.89 & 0.73 & 0.79 & 0.80 & 0.30 & 0.84 & 0.81 & 1.00 & & & & & & & & & & & & & & \\
\hline G19 & 0.68 & 0.73 & 0.80 & 0.74 & 0.68 & 0.76 & 0.69 & 0.74 & 0.74 & 0.86 & 0.77 & 0.87 & 0.72 & 0.68 & 0.47 & 0.72 & 0.88 & 0.73 & 1.00 & & & & & & & & & & & & & \\
\hline G20 & 0.64 & 0.68 & 0.78 & 0.66 & 0.70 & 0.83 & 0.82 & 0.63 & 0.63 & 0.83 & 0.93 & 0.73 & 0.79 & 0.83 & 0.30 & 0.82 & 0.81 & 0.85 & 0.80 & 1.00 & & & & & & & & & & & & \\
\hline G21 & 0.64 & 0.59 & 0.71 & 0.69 & 0.58 & 0.73 & 0.63 & 0.63 & 0.66 & 0.76 & 0.65 & 0.76 & 0.63 & 0.57 & 0.50 & 0.65 & 0.73 & 0.60 & 0.83 & 0.70 & 1.00 & & & & & & & & & & & \\
\hline G22 & 0.67 & 0.69 & 0.80 & 0.65 & 0.75 & 0.78 & 0.81 & 0.66 & 0.65 & 0.79 & 0.88 & 0.74 & 0.69 & 0.79 & 0.30 & 0.81 & 0.84 & 0.78 & 0.81 & 0.86 & 0.69 & 1.00 & & & & & & & & & & \\
\hline G23 & 0.57 & 0.66 & 0.71 & 0.65 & 0.68 & 0.78 & 0.75 & 0.62 & 0.55 & 0.80 & 0.84 & 0.66 & 0.73 & 0.83 & 0.30 & 0.76 & 0.78 & 0.82 & 0.71 & 0.83 & 0.70 & 0.80 & 1.00 & & & & & & & & & \\
\hline G24 & 0.64 & 0.63 & 0.78 & 0.68 & 0.71 & 0.71 & 0.76 & 0.56 & 0.65 & 0.68 & 0.81 & 0.69 & 0.65 & 0.71 & 0.26 & 0.76 & 0.73 & 0.69 & 0.70 & 0.79 & 0.64 & 0.81 & 0.75 & 1.00 & & & & & & & & \\
\hline G25 & 0.65 & 0.71 & 0.84 & 0.80 & 0.71 & 0.93 & 0.73 & 0.70 & 0.66 & 0.85 & 0.77 & 0.75 & 0.75 & 0.68 & 0.35 & 0.81 & 0.83 & 0.77 & 0.82 & 0.79 & 0.71 & 0.75 & 0.70 & 0.70 & 1.00 & & & & & & & \\
\hline G26 & 0.63 & 0.65 & 0.79 & 0.64 & 0.70 & 0.81 & 0.80 & 0.60 & 0.61 & 0.78 & 0.89 & 0.68 & 0.72 & 0.78 & 0.26 & 0.80 & 0.79 & 0.80 & 0.77 & 0.88 & 0.69 & 0.91 & 0.79 & 0.82 & 0.80 & 1.00 & & & & & & \\
\hline G27 & 0.59 & 0.64 & 0.75 & 0.65 & 0.70 & 0.81 & 0.80 & 0.62 & 0.60 & 0.83 & 0.91 & 0.72 & 0.83 & 0.83 & 0.29 & 0.85 & 0.81 & 0.89 & 0.77 & 0.93 & 0.67 & 0.84 & 0.88 & 0.79 & 0.79 & 0.85 & 1.00 & & & & & \\
\hline G28 & 0.57 & 0.50 & 0.56 & 0.56 & 0.57 & 0.50 & 0.65 & 0.48 & 0.56 & 0.52 & 0.53 & 0.50 & 0.63 & 0.54 & 0.44 & 0.57 & 0.50 & 0.54 & 0.52 & 0.55 & 0.40 & 0.59 & 0.45 & 0.57 & 0.54 & 0.57 & 0.55 & 1.00 & & & & \\
\hline G29 & 0.59 & 0.69 & 0.73 & 0.67 & 0.72 & 0.75 & 0.78 & 0.63 & 0.60 & 0.81 & 0.92 & 0.72 & 0.75 & 0.85 & 0.29 & 0.80 & 0.83 & 0.86 & 0.79 & 0.89 & 0.63 & 0.85 & 0.87 & 0.81 & 0.74 & 0.85 & 0.93 & 0.53 & 1.00 & & & \\
\hline G30 & 0.61 & 0.65 & 0.76 & 0.66 & 0.75 & 0.72 & 0.81 & 0.60 & 0.62 & 0.75 & 0.88 & 0.78 & 0.69 & 0.85 & 0.27 & 0.83 & 0.80 & 0.80 & 0.75 & 0.85 & 0.63 & 0.88 & 0.78 & 0.87 & 0.71 & 0.83 & 0.87 & 0.57 & 0.91 & 1.00 & & \\
\hline G31 & 0.60 & 0.59 & 0.71 & 0.65 & 0.64 & 0.76 & 0.72 & 0.54 & 0.61 & 0.73 & 0.86 & 0.67 & 0.75 & 0.80 & 0.33 & 0.75 & 0.75 & 0.81 & 0.73 & 0.87 & 0.63 & 0.80 & 0.79 & 0.79 & 0.75 & 0.84 & 0.92 & 0.62 & 0.92 & 0.86 & 1.00 & \\
\hline G32 & 0.69 & 0.73 & 0.78 & 0.80 & 0.69 & 0.69 & 0.65 & 0.73 & 0.74 & 0.83 & 0.75 & 0.84 & 0.70 & 0.70 & 0.44 & 0.70 & 0.85 & 0.69 & 0.88 & 0.75 & 0.72 & 0.74 & 0.74 & 0.75 & 0.75 & 0.69 & 0.78 & 0.52 & 0.80 & 0.77 & 0.72 & 1.00 \\
\hline Mean & 0.63 & 0.67 & 0.74 & 0.69 & 0.69 & 0.74 & 0.72 & 0.64 & 0.63 & 0.76 & 0.77 & 0.71 & 0.69 & 0.70 & 0.37 & 0.74 & 0.77 & 0.74 & 0.75 & 0.77 & 0.66 & 0.75 & 0.72 & 0.71 & 0.74 & 0.74 & 0.76 & 0.54 & 0.76 & 0.75 & 0.73 & 0.73 \\
\hline
\end{tabular}




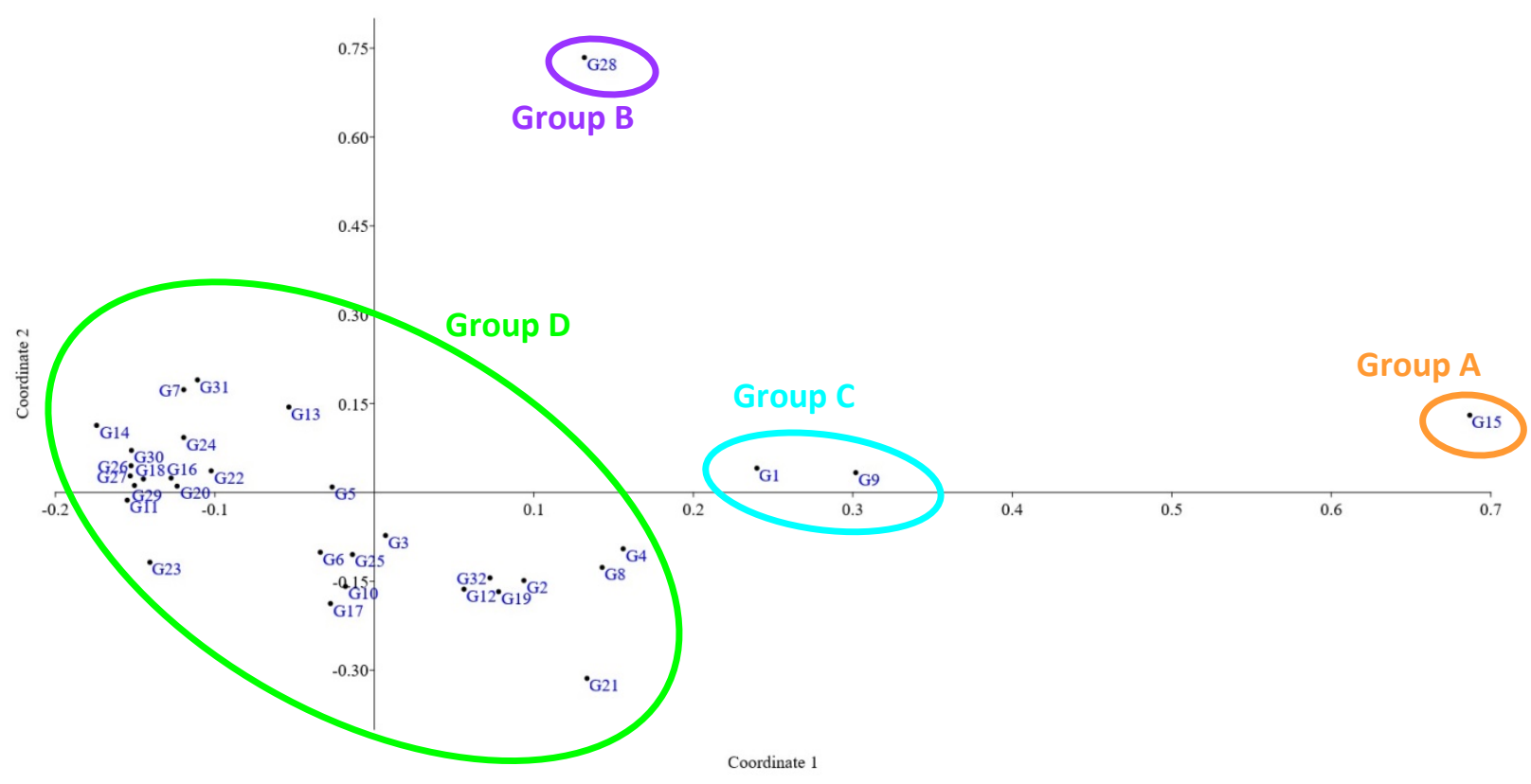

Figure 2. Clustering of tomato accessions through Principal Coordinate Analysis (PCoA).

STRUCTURE analysis performed to examine population structure the most probable $\mathrm{K}$ value was 2 (Figure 4). According to this $\mathrm{K}$ value, the tomato accessions were separated into 2 subpopulations (Figure 3). The first subpopulation included 18 accessions, while the second subpopulation comprised 14 accessions. (Henareh et al., 2016) assessed the genetic variation of Turkey and Iran tomato accessions. They determined two sub-populations by STRUCTURE analysis and genetic variation in sub-population 2 was higher than sub-population 1. When membership coefficient in individual of a subpopulation is 0.8 or higher, this individual is accepted as pure. Lower membership coefficients are accepted as mixed of at least two different subpopulations (Fukunaga et al., 2005). In our study, 28 accessions had 0.8 or higher membership coefficient; therefore, these accessions can be said to be pure.

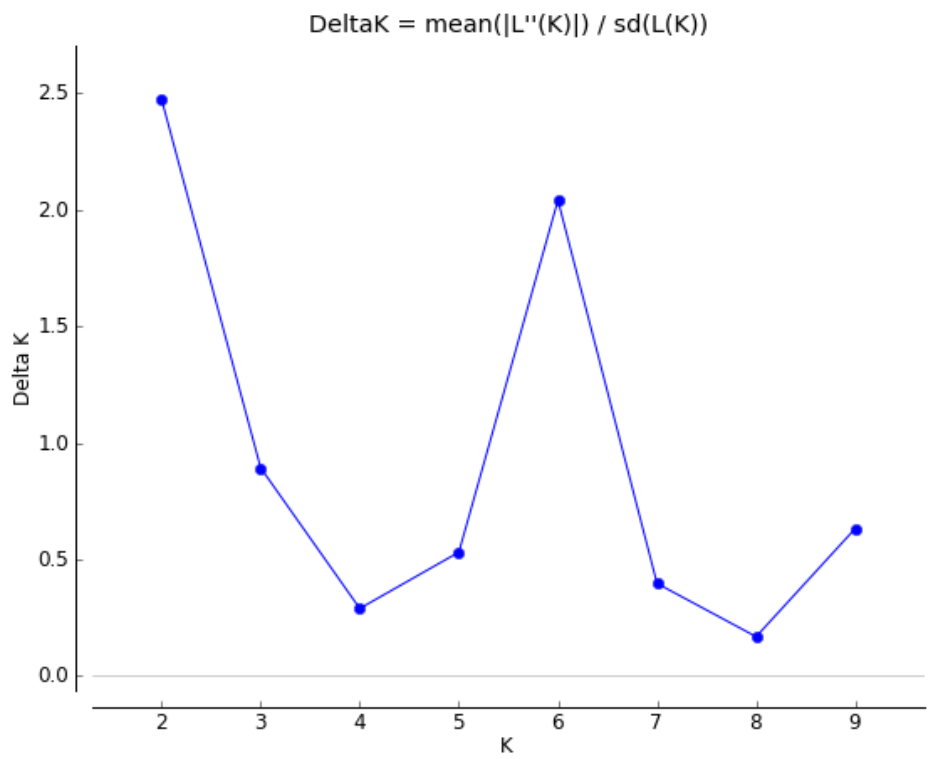

Figure 3. Delta $\mathrm{K}$ values for different numbers of populations expected (K) in the STRUCTURE analysis. 

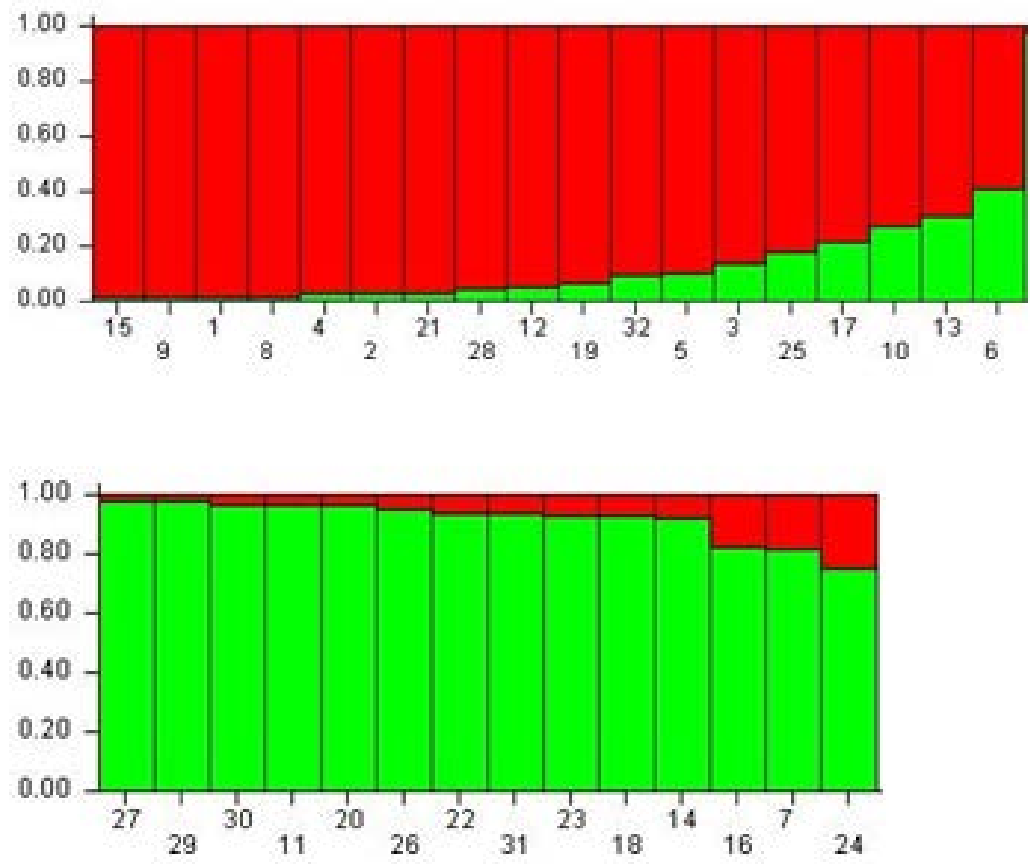

\section{Subpopulation}

II. Subpopulation

Figure 4. Estimation of population structure with Bayesian model.

\section{Conclusions}

In the present study, the ISSR marker system was used to put forward the genetic diversity and population structure that can conceivably be applied for selection of proper parents to present greater genetic variation in tomato breeding programs and help the breeders in the tomato. ISSR markers gave high polymorphism rate and genetic variation was determined in tomato accessions. This study reveals that the ISSR marker system is a helpful and easy method for fingerprinting and distinguishing tomato accessions because of its easy using and reliability. It was thought that analysis of these accessions will lead to the collection of information about the genetic diversity at the genome level; also it is believed that this studied tomato gene pool will be a significant genetic resource in next breeding studies and will contribute the facility of germplasm management. For subsequent studies, the detailed identification of these genotypes in terms of phenotypic and molecular properties becomes important for future breeding studies.

\section{Acknowledgements}

This study was funded by the project \# 2015-FBE-YL360 of Scientific Research Projects Council of Van Yuzuncu Yil University. This study was produced from M.Sc. thesis of the first author.

\section{References}

Abak, K., Şensoy, S., Sarı, N., \& Alan, A. R. (1996). Bazı önemli sanayi domates çeşitlerinin Harran Ovası koşullarındaki verim ve kaliteleri. GAP I. Sebze Tarımı Sempozyumu, 11-18.

Aguilera, J. G., Pesson, L. A., Rodrigues, G. B., Elsayed, A.Y., da Silva, D. J. H., \& de Barros, E. G. (2011). Genetic variability by ISSR markers in tomato (Solanum lycopersicon Mill.). Revista Brasileira de Ciências Agrárias, 6(2), 243-252.

Al-Tamimi, A. J. T., Al-Saadi, A. H., \& Abbass, M. C. (2015). Genetic diversity of some tomato Lycopersicon esculentum Mill varieties in Iraq using Simple Sequence Repeat (SSR) Markers. Magazin of Al-Kufa University for Biology, 7(1), 64-80. 
Antonio, Garcia, L. L., Benchimol, A. M. M., Barbosa, I. O.,Geraldi, C. L., Jr, S., \& Souza, A. P. D. (2004). Comparison of RAPD, RFLP, AFLP and SSR markers for diversity studies in tropical maize in bred lines. Genetics and Molecular Biology, 27(4), 579-588.

Bayram, M., Sensoy, S., H. Y., \& Dasgan. (2011). Iron (Fe) deficiency tolerance in tomato recombinant inbred lines obtained from tolerant and sensitive genotypes. Acta Horticulturae, 918, 575-582.

Bredemeijer, G. M. M., Paul, A., Doret, W., \& Vosman, B. (1998). The use of semi-automated fluorescent microsatellite analysis for tomato cultivar identification. Theoretical and Applied Genetics, 97(4), 584-590.

Doyle, J. J., \& Doyle, J. L. (1987). A rapid DNA isolation procedure from small quantities of fresh leaf tissues. Phytochemical Bulletin, 19, 11-15.

Ekincialp, A., \& Şensoy, S. (2018). Phenotypic and molecular determination of anthracnose disease resistance in Lake Van Basin's bean genotypes (Phaseolus vulgaris L.). Legume Research, 41, 135-142.

Ekincialp, A., Erdinc, C., Turan, S., Cakmakci, O., Nadeem, M. A., Baloch, F. S., \& Sensoy., S. (2019). Genetic characterization of Rheum ribes (wild rhubarb) genotypes in Lake Van Basin of Turkey through ISSR and SSR markers. Intl. J. Agric. Biol, 21, 795-802.

Erdinç, Ç., Ekincialp, A., Yıldız, M., Kabay, T., Türkmen, Ö., \& Şensoy, S. (2013). Molecular genetic diversity in Lake Van Basin melons (Cucumis melo L.) based on RAPD and ISSR markers. YYU J AGR SCI, 23, 264-270.

Erdinc, C., Turkmen, O., Dasgan, H. Y., \& Şensoy, S. (2017). Phenotypic and molecular genetic diversity among some Turkish bean genotypes. The Journal of Animal and Plant Sciences, 27(6), 1963-1973.

Figueiredo, A. S. T., Resende, J. T. V., Faria, M. V., Da-Silva, P. R., Fagundes, B. S., \& Morales, R. G. F. (2016). Prediction of industrial tomato hybrids from agronomic traits and ISSR molecular markers. Genetics and Molecular Research, 15(2), 1-13.

Foolad, M. R. (2007). Genome mapping and molecular breeding of tomato. Int J Plant Genomics, 27, $1-52$.

Fukunaga, K., Hill, J., Vigouroux, Y., Matsuoka, Y., Sanchez, G. J., Liu, K., Buckler, E. S., \& Doebley, J. (2005). Genetic diversity and population structure of Teosinte. Genetics, 169, 2241-2254.

Furan, M. A., \& Geboloğlu, M. D. (2017). Assessment of genetic variation on some cultivated Turkish coriander (Coriandrum sativum L.) varieties based on ISSR and SRAP markers. YYU J AGR SCI, 27(2), 245-251.

Garcia, A. A. F., Benchimol, L. L., Barbosa, A. M. M., Geraldi, I. O., Souza, Jr., C. L., \& de Souza, A. P. (2004). Comparison of RAPD, RFLP, AFLP and SSR markers for diversity studies in tropical maize in bred lines. Genetics and Molecular Biology, 27(4), 579-588.

García-Martínez, S., Andreani, L., Garcia-Gusano, M., Genua, F., \& Ruiz, J. J. (2006). Evaluation of amplified fragment length polymorphism and simple sequence repeats for tomato germplasm fingerprinting: utility for grouping closely related traditional cultivars. Genome, 49(6), 648-656.

He, C., Poysa, V., \& Yu, K. (2003). Development and characterization of simple sequence repeat (SSR) markers and their use in determining relationships among Lycopersicon esculentum cultivars. Theoretical Applied Genetics, 106, 363-373.

Henareh, M., Dursun, A., Abdollahi Mandoulakani, B., \& Haliloğlu, K. (2016). Assessment of genetic diversity in tomato landraces using ISSR markers. Genetika, 48(1), 25-35.

Kamel, M. A., Soliman, S. S., Mandour, A. E., Mahassen \& Ahmed, S. S. (2010). Genetic evaluation and molecular markers for heat tolerance in tomato (Lycopersicon esculentum Mill.). Journal of American Science, 6(12), 364-374.

Kiani, G., \& Siahchehreh, M. (2018). Genetic diversity in tomato varieties assessed by ISSR markers. International Journal of Vegetable Science, 24:4, 353-360. DOI: 10.1080/19315260.2017.1419397.

Kochieva, E. Z., Ryzhova, N. N., Khrapalova, I. A., \& Pukhalskyi, V. A. (2002). Genetic diversity and phylogenetic relationships in the genus Lycopersicon (Tourn.) Mill. as revealed by Inter-Simple Sequence Repeat (ISSR) analysis. Russian Journal of Genetics, 38(8), 958-966.

Korir, N. K., Diao, W., Tao, R., Li, X., Kayesh, E., Li, A., Zhen, W., \& Wang, S. (2014). Genetic diversity and relationships among different tomato varieties revealed by EST-SSR markers. Genetics and Molecular Research, 13(1), 43-53. 
Masumbuko, L., \& Bryngelsson, T. (2006). Inter Simple Sequence Repeat (ISSR) analysis of diploid coffee species and cultivated Coffea arabica L. from Tanzania. Genetic Resources and Crop Evolution, 53(2), 357-366.

Meng, F., Xu, X., Feng-lan, Huang, F., \& Li, J. (2010). Analysis of genetic diversity in cultivated and wild tomato varieties in chinese market by RAPD and SSR. Agricultural Sciences in China, 9(10), 1430-1437.

Muthusamy, S., Kanagarajan, S., \& Ponnusamy, S. (2008). Efficiency of RAPD and ISSR markers system in accessing genetic variation of rice bean (Vigna umbellata) landraces. Electronic Journal of Biotechnology, 11(3), 32-41.

Pharmawati, M., Yan, G., \& McFarlane, I. J. (2004). Application of RAPD and ISSR markers to analyse molecular relationships in Grevillea (Proteaceae). Australian Systematic Botany, 17, 49-61.

Powell, W., Morgante, M., Andre, C., Hanafey, M., Vogel, J., Tingey, S., \& Rafalski, A. (1996). The comparison of RFLP, RAPD, AFLP and SSR (microsatellite) markers for germplasm analysis. Molecular Breeding, 2(3), 225-238.

Pritchard, J. K., Stephens, M., \& Donnelly, P. (2000). Inference of population structure using multilocus genotype data. Genetics, 155, 945-959.

Reddy, M.P., Sarla, N., \& Siddiq, E. (2002). Inter Simple Sequence Repeat (ISSR) polymorphism and its application in plant breeding. Euphytica, 128(1), 9-17.

Sharifova, S., Mehdiyeva, S., Theodorikas, K., \& Roubos, K. (2013). Assessment of genetic diversity in cultivated tomato (Solanum Lycopersicum L.) genotypes using raped primers. Journal of Horticultural Research, 21(1), 83-89.

Shahlaei, A., Torabi, S., \& Khosroshahli, M. (2014). Efficiacy of SCoT and ISSR marekers in assesment of tomato (Lycopersicum esculentum Mill.). Int. J. Biosci, 5(2), 14-22.

Smith, J., Chin, E., Shu, H., Smith, O., Wall, S., Senior, M., Mitchell, S., Kresovich, S., \& Ziegle, J. (1997). An evaluation of the utility of SSR loci as molecular markers in maize (Zea mays L.): Comparisons with data from RFLPs and pedigree. Theoretical and Applied Genetics, 95, 163173.

Smolik, M., Zielinski, J., Danuta, R. P., \& Katarzyna, A. (2006). Polymorphism of microsatellite sequences in morphologically and phenologically different genotypes of Lonicera periclymenum. Journal of Food, Agriculture and Environment, 4(2), 226-233.

Suhartanto, M. R. (2002). Chlorophyll in tomato seeds: marker for seed performance? Wageningen,The Netherlands, 1-150.

Suliman-Pollatschek, S., Kashkush, K., Shats, H., Hillel, J., \& Lavi, U. (2002). Generation and mapping of AFLP, SSRs and SNPs in Lycopersicon esculentum. Cell Mol Biol Lett, 7(2A), 583-597.

Tabassum, N., Sony, S. K., Bhajan, S. K., \& Islam, M. N. (2013.) Analysis of genetic diversity in eleven tomato (Lycopersicon esculentum Mill.) varieties using RAPD markers. Plant Tissue Culture and Biotechnology, 23(1), 49-57.

Tam, S. M., Mhiri, C., Vogelaar, A., Kerkveld, M., Pearce, S. R., \& Grandbastien, M. (2005). Comparative analyses of genetic diversities within tomato and pepper collections detected by retrotransposon-based SSAP, AFLP and SSR. Theor Appl Genet, 110, 819-831.

Terzopoulos, P., \& Bebeli, P. (2008). DNA and morphological diversity of selected Greek tomato (Solanum lycopersicum L.) landraces. Scientia Horticulturae, 116, 354-361.

Thamir, A.J., Al-Saadi, A. H., \& Abbass, M. C. (2014). Genetic diversity of some tomato Lycopersicon esculentum Mill varieties in Iraq using Random Amplified Polymorphic DNA (RAPD) Markers. Ournal of Babylon University/Pure and Applied Sciences, 9(22), 2342-2351.

Tikunov, Y. M., Khrustaleva, L. I., \& Karlov, G. I. (2003). Application of ISSR markers in the genus Lycopersicon. Euphytica, 131(1), 71-80.

Todorovska, E., Ivanova, A., Ganeva, D., Pevicharova, G., Molle, E., Bojinov, B., Radkova, M., \& Danailov, Z. (2014). Assessment of genetic variation in Bulgarian tomato (Solanum lycopersicum L.) genotypes, using fluorescent SSR genotyping platform. Biotechnology and Biotechnological Equipment, 28(1), 68-76.

Topakl1, F., \& Hepaksoy, S. (2019). Overall assessment of the molecular analysis of olives in Turkey. YYU J AGR SCI, 29(2), 362-372.

Vargas-Ponce, O., Pérez-Álvarez, L. F., Zamora-Tavares, P., \& Rodríguez, A. (2011). Assessing genetic diversity in Mexican husk tomato species. Plant Mol. Biol. Rep, 29, 733-738. 
Vishwanath, K., Prasanna, K. P. R., Pallavi, H. M., Prasad, R. S., Ramegowda Devaraju, P. J., \& Ananthararayanan, T. (2011). Identification of tomato (Lycopersicon esculentum) varieties through total soluble seed proteins. Research Journal Agrilculture Science, 2(1), 08-12.

Williams, J. G. K., Kubelik, A. R., Livak, K. J., Rafalski, J. A., \& Tingey, S. V. (1990). DNA polymorphisms amplified by arbitrary primers are useful as genetic markers. Nucl. Acids Res, 18(22), 6531-6535. 